\title{
Life-Skill Literacy Education Towards Rural Industrial Development
}

\author{
Achmad Hufad, Jajat S.Ardiwinata, Purnomo \\ Department of Non-formal Education, \\ Universitas Pendidikan Indonesia \\ Bandung \\ achmadhufad@upi.edu
}

\begin{abstract}
Rural area is identified by the agricultural and farming commodity and close-tied kinship of the community. Nevertheless, the education level is low. More women in the rural areas, however, suffer from illiteracy compared those living the cities. This is the case due to the insufficient education facility and the remote geographical location. Despite the fact, countryside women have a handful of skills that support the industry development in agricultural or farming of which results are distributed to the cities. This study utilized the vocational training approach to teach literacy to the countryside women to enable them to read and write as well as reinforcing learning motivation. This research was conducted in Pagerwangi Countryside in Lembang, West Java Province. Aiming to reveal a skill as approach in literacy learning towards rural industrial. This study used a qualitative approach, the case study method. Based on the results of the study, that the completion of illiteracy through skills can increase the motivation of adult learning and preparing for independent/ autonomy community towards rural industries.
\end{abstract}

\section{Keywords-rural area industry, illiteracy, life-skill education}

\section{INTRODUCTION}

Literacy is a nation issue and the government highly promotes literacy education to eradicate illiteracy in Indonesia. There are significant gaps among literacy in men and women. Likewise, literacy gaps occur among women who live in the city and countryside, both in Indonesia and India. Research [1], [2] show literacy education is a community empowering effort. It is also a public policy and democracy process [1].

Literacy education is a powerful weapon to battle injustice, poverty, and health problems, all of which were mostly experienced by women. Above all, literacy is the parameter showing the rise and depth of social-economy development [2].

Literacy in Bandung City and Regency in 2010, based on the Statistic Center Bureau cited by the Ministry of Education [3], was wide-ranging. Table 1 shows that the Bandung city area suffer the least illiteracy compared to the two rural areas, namely Bandung Regency and Bandung Barat Regency. However, in the three areas reported, more female residents were unlettered than male residents.
TABLE I.

\begin{tabular}{|l|l|l|l|}
\hline No. & \multicolumn{1}{|c|}{ City/ Regency } & Male & \multicolumn{1}{|c|}{ Female } \\
\hline 1 & Bandung City & 1,596 & 2,666 \\
\hline 2 & Bandung Regency & 6,494 & 11,164 \\
\hline 3 & Bandung Barat Regency & 4,562 & 8,756 \\
\hline
\end{tabular}

The highest population dispersion of Bandung Barat Regency is $11.58 \%$ at Lembang District. The second largest population is $10.32 \%$ at Padalarang District and $10.20 \%$ in Ngamprah District [4]. Study shows that high population dispersion is prone to poverty.

There are 44,926 households and 6,818 are under poverty [5]. Unlettered female in the community were given education in the Community Learning Center. Among the activity held by the Community Learning Center was the literacy education. Joint-research conducted by the Non-formal Education Department of Universitas Pendidikan Indonesia and the Center of Research and Community Service resulted in the potential contribution of unlettered women to the industry in the rural areas.

Since the 80s, Pagerwangi Countryside in Lembang has been producing food products made of cassava, namely kecimpring or opak- the crackers. Opak was then produced and packed conventionally. The flavoring and shape was also less varied. But this tradition changed as the literacy education for women given by the Community Learning Center resulted in positive learning outcomes. Following the learning, the community was able to create more varied products and more advanced package. Moreover, license from the Health Department was gained. The transformation in food production did not, however, occur overnight and it was successful because of the participation of the community.

During the life-skill learning in which the unlettered women was taught to innovate cassava products, the Community Learning Center facilitators also included the literacy learning. That way, the women would not only able to transform their conventional production but also able to read and write. Previous studies [6], [7] explained that life-skills are to encourage learning motivation in a community due to the fact that they are adults and the learning materials that are related and significant to their life.

The failure of literacy program is no sustainable program, many are illeterate back, because the motivation of adults to 
decline, but learning which can solve the problems of life, especially increased revenue is very interested by adult to learn.

\section{RESEARCH METHOD}

This research is qualitative in nature and describes the conditions and behaviors of the learning community as well as the program administrators. The result of the study is presented in a narrative that interprets the skill and administrative of the literacy learning. Data were obtained from the field notes, documentations, observation, and interviews [8].

The subjects of the study were the program administrators and the learning community. The objective of the study was to describe the life-skill literacy learning in Pagerwangi Countryside in Lembang.

\section{RESULTS OF THE STUDY}

\section{A. The Teaching-learning Activity}

The content of the life-skill literacy learning focused on the skills that have been emerging in the countryside. Need assessment of the learning resulted in the skills that were desired by the community. To name a few were baking, sewing, and innovating the cassava products, i.e. the simping and opak. However, among the three skills, the skill to produce the opak was mostly desired because the community has prepared the skill to fulfill the market demands. Literacy curriculum was then designed to solve the problems within the community.

The teaching-learning activity was conducted mainly in a form of discussion in a friendly atmosphere. There were no chairs and desks involved that everyone gathered on a floor and conversed with snacks being served. The leaders of the community would occasionally join the activity.

Most activities initiated with discussion between the facilitators and participants to reflect the previous learning materials and discuss the current learning materials. Then, practices that integrated reading, writing, and arithmetic were conducted. The session ended with a discussion and practical activities individually or in groups.

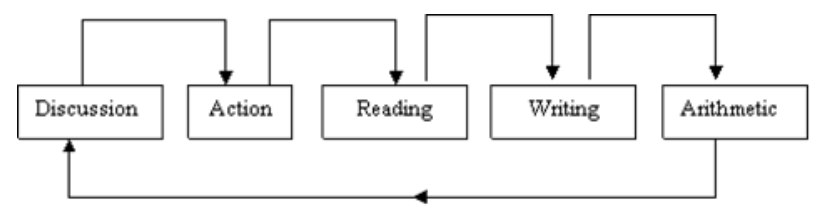

Fig. 1. Flow Chart of the Life-skill Literacy Learning

Despite the importance of cognitive and affective aspects, this learning emphasized psychomotor skill of the participants. This is the case because the learning not only aimed at enabling participants' writing, reading and arithmetic skill, but also providing skills that supports their life in general. To that end, facilitators were required to motivate participants to use the skills in their daily life to enhance the quality of their life.

\section{B. The Learning Outcomes}

The overall learning outcomes of the literacy were good, both quantitatively and qualitatively. Quantitatively, the number of participants who actively attended the learning was many. The participants were found to be able to use the literacy skill in their life. They were also found to able to conduct peer-training, in which they helped the participants to understand better and passed on the knowledge to the nonparticipating community members.

\section{DISCUSSION}

Numerous studies show that Community Learning Center is an education unit to encourage character developments as well as a training center to gain lifeskills with which community members enhance their quality of life and their income $[9,10]$.

Andragogy learning approach to train literacy skill is suitable to solve adults' learning problems. Therefore, the facilitators stimulated the participants' thinking through discussion sessions and practices with the available technology. Literacy growth was gained because the participants actively used the knowledge in day-to-day interactions $[6,7,11]$.

Benefiting the commodity, that is raw food production and distribution to the cities, it was necessary to prioritize the countryside's development, especially the development of the women in the community. The cassava-based food produces have some benefits, for example, cassava contains lower carbohydrate compared to rice and is manufactured into snacks, cookies, chips, and rasi - the cassava rice. Therefore, the countryside's commodity is even more varied [14].

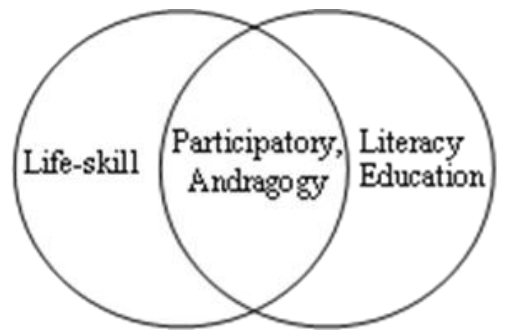

Fig. 2. Life-skill Literacy Learning Approach

The learning program was flexible that it suited to the participants' need. The curriculum was also contextual that it was easier for the tutor to search for the suitable teaching materials. These principles were aligned to the literacy education principles, they are 1) locally designed, 2) Contextual, 3) Functional, 4) Participatory [6]. Adhering to the four principles, the literacy learning was conducted with high appreciation, consideration, and cooperation [7].

Implementing andragoy learning approach, the literacy learning applied problem-solving, brainstorming, demonstration, discussion and lecture learning activities. All these activities aimed at stimulate the participants' learning motivation. Meanwhile, vocational approach was applied to 
train the life skill to enhance their welfare and income. The participatory-andragogy learning approach resulted in a significant cognitive, affective, and psychomotor growth. The participants' income was reported to progressively increasing. Aside from that, the participants were found to be more tolerant and emphatic, eager to learn from one another, and motivated [12].

Lastly, the result of the teaching-learning activity was continuously increasing under the learning of the tutors. Some of the roles of the tutor were to maintain the learning condition and environment, to provide information and solution found in the community. Previous study proved that following life-skill learning program, communities exhibited independence by being able to innovatively pack end products, communicate well, own confidence, and develop their creativity [13].

\section{CONCLUSIONS}

Literacy education program is both national and international concern. Statistics shows that women are more prone to illiteracy compared to men and those living in the countryside suffer illiteracy more than those living the city. Special approach to the literacy education program is required to increase their economy and to provide solution to the social problem. Despite the rich natural resource and economy value, the education level is rather low. To this end, a learning program was designed to increase both the countryside's economy and the community's education level. Lastly, the learning served as an empowering tool with which the community will be able to be technology-literate in the future.

\section{ACKNOWLEDGEMENT}

We would like to express our deepest gratitude to LPPM UPI (Institute of Research and Community Service of Indonesia University of Education) for the research grant. We would like to also appreciate Mr. Dadang Yunus as the CLC Chairman who has helped the research from the beginning to its completion.

\section{REFERENCES}

[1] Caroline O, Omobola O, "Political empowerment of women through literacy education programmes in EDO and Delta States, Nigeria,' Journal of Adult and Continuing Education - Volume 21 No.2 Autumn 2015 .

[2] [2] Shiv Prakash Katiyar, "Gender disparaty in Literacy in India," SAGE Publication 46-69, 2016

[3] [3] Angka Buta Aksara tahun. (2016) Tersedia: http://bindikmas.kemdikbud.go.id. Diakses 2 Januari 2016.

[4] [4] BPS Kabupaten Bandung Barat. (2013). Tersedia: http://bandungbaratkab.bps.go.id/konten_statistik.php?kat=1. Diakses 31 Desember 2014

[5] [5] Laporan Pokjanal Posyandu Kabupaten Bandung Barat. (2013). Tersedia:http://www.siposyandukbb.com/sites/default/files/filepdf/LAP ORAN\%20POKJANAL\%20POSYANDU\%20KBB\%202013\%20FIX.p df Diakses 31 Desember 2014

[6] [6] Purnomo, "strategi pembelajaran pendidikan keaksaraan tingkat

[7] lanjutan melalui vokasional skill menjahit di pkbm ash-shoddiq desa pagerwangi kecamatan lembang kabupaten bandung," e-journal.upi.edu, Vol 5, No 2, 2010

[8] [7] Sukmana, C. "pengaruh metode penyadaran dalam meningkatkan minat baca warga belajar keaksaraan (studi dilakukan pada lembaga pusat kegiatan belajar masyarakat di kecamatan cimahi selatan, kota cimahi)", e-journal.upi.edu, Vol 8, No 1, 2012.

[9] [8] Sugiyono. (2009). "Metode Penelitian Kuantitatif Kualitatif dan R\&D. Bandung: Alfabeta

[10] [9] Murti, N.W. (2015). "Model "Roket Peluncur" Untuk Mewujudkan Pusat Kegiatan Belajar Masyarakat (PKBM) Sebagai Lembaga Pendidikan yang Berbasis Life Skill dan Mandiri”. Jurnal Ilmu Berbagai. Vol. 2014, No 3: Seri Ilmu Sosial dan Pendidikan, Januari 2015 .

[11] [10] Azhar. (2011). "Model Pembelajaran Kewirausahaan Pada PKBM Binaan SKB Kabupaten Temanggung”. Jurnal Kependidikan, Vol. 41, No 1, Mei 2011, Hal 11-22.

[12] [11] Setiawan, W. (2016). "Model Pembelajaran Partisipatif Dalam Meningkatkan Kemandirian Perempuan Sebagai Kepala Keluarga". Bandung: Disertasi, Universitas Pendidikan Indonesia (UPI).

[13] [12] Lutfiansyah, D "Pendidikan Kecakapan Hidup (Life Skills) Dalam Pemberdayaan Perempuan Kepala Keluarga (Pekka) Untuk Peningkatan Pendapatan Dan Kemandirian Berwirausaha," e-journal.upi.edu, vol. 4. No 2, 2009.

[14] [13] Achmad. H, Jajat. S, Purnomo "Mentoring of Women's Empowerment Program". International Journal of Applied Enviromental Sciences, ISSN 0973-6077 Vol.11, No. 4, pp.873-879, 2016.

[15] [14] Achmad. H, Jajat. S, Purnomo "A Model of Cultural Survival of Sundanese Ethnic Community". 1st UPI International Conference on Sociology Education, ISSN 2352-5398, vol. 34, 2015 